\title{
動的平衡海浜に建設されたヘッドランド群の 漂砂制御効果の定量的評価
}

\begin{abstract}
宇多高明 ${ }^{1} \cdot$ 石井 隆 $^{2} \cdot$ 杉山喜一郎 $^{3} \cdot$ 西谷 $^{\text {誠 }}{ }^{4}$

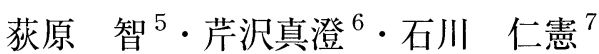

等深線変化モデルを清水海岸の離岸堤群式ヘッドランド周辺の海浜変形予測に適用し，ヘッドランド設置以前には $13 \times$ $10^{4} \mathrm{~m}^{3} / \mathrm{yr}$ の沿岸漂砂が流れる動的平衡状態にあったが，施設の建設により沿岸漂砂量が $7 \times 10^{4} \mathrm{~m}^{3} / \mathrm{yr}$ に低減された新し い平衡状態に達したことを明らかにした，その上で，将来の侵食対策について検討したところ，既設離岸堤を下手・上手方 向に $50 \mathrm{~m}$ 延長して間隔を狭めると, 現況の養浜量を $0.5 \sim 1.0 \times 10^{4} \mathrm{~m}^{3}$ 程度低隇させることができることが分かった.
\end{abstract}

\section{1.まえがき}

静岡・清水海岸は安倍川河口より三保松原砂嘴の外縁 に沿って延びた長さ約 $17 \mathrm{~km}$ の砂浜海岸である。この 海岸では, 安倍川での広範な砂利採取が行われる以前, ほぼ $13 \times 10^{4} \mathrm{~m}^{3} / \mathrm{yr}$ の沿岸漂砂が北向きに流れ, 砂嘴 北端部に堆積するとともに一部は海底谷を経由して深海 へと落ち込んでいた（宇多，1997）。しかし1967年まで 続いた安倍川での砂利採取に伴って河川流出土砂量が激 減し，同時にその影響が erosion wave として伝播し始 めた．その後河川での砂利採取の停止とともに 1983 年 から安倍川河口から発生した accretion wave が静岡海 岸から清水海岸方面へと伝播しつつある。一方, erosion wave が到達しつつあった三保松原先端部に近い清 水海岸では, 1983 年頃激しい侵食を受けたことから 2 基の離岸堤からなるへッドランド群が造られ，その間の 汀線の安定化を図ることとなり, 現在は 5 組のヘッドラ ンド群が完成している. 施工後, ヘッドランド群の直下 手では汀線がフック状に後退し, 護岸が露出するととも にその倒壊が危惧される状態となっている．またこれら のヘッドランド群周辺では自然に供給される沿岸漂砂量 が少ないために毎年約 $3.5 \times 10^{4} \mathrm{~m}^{3}$ の養浜が行われてい るが，この工事に費用が䘱むことから侵食を激化させず に養浜量を隇少させ，コストの軽隇ができないかどうか が課題となっている。このことから，本研究では，まず 清水海岸の特性である沿岸漂砂により動的平衡状態にあ る海浜形状を 3 次元的意味から等深線変化モデルにより 再現した上で，施設形状と種類を変えつつ，養浜量の低 減の可能性について検討する.

\begin{tabular}{|c|c|c|}
\hline 1 正会員 & 工博 & (財) 土木研究センター理事なぎさ総合研究室長 \\
\hline . & & (財)静岡県総合管理公社 建設技術部長 \\
\hline 3 & & 静岡県島田土木事務所 工事第 3 課 副主任 \\
\hline 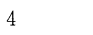 & & 静岡県静岡土木事務所 清水支所 主幹 \\
\hline & & 静岡県静岡土木事務所 清水支所 主任 \\
\hline & & 海岸研究室 (有) \\
\hline & 工修 & (財) 土木研究センターなぎさ総合研究室 \\
\hline
\end{tabular}

\section{2. 対象地域の漂砂特性}

検討対象区域は図-1に示す三保松原砂嘴の外縁に位 置する清水海岸の No. 54 No. 68 の区域である.この 付近の海岸沖には緩勾配の大陸棚が発達しているが，北 側の No. 30 付近には急峻な海底谷が迫る.清水海岸の 離岸堤群式ヘッドランドの建設に伴う海浜変形について は宇多（1997）に詳しい分析結果が示されている．図-2 はこの資料を引用したものである。1988 年には沖合の 等深線が䋧やかに湾曲した汀線と平行に延び，前浜から 水深約 $5 \mathrm{~m}$ まで約 $1 / 10$ と急勾配で落ち込んだ後，1/50 と緩勾配の海底面となっていた．宇多（1997）によれば, このように自然状態にあった清水海岸にあっては，ほほ $13 \times 10^{4} \mathrm{~m}^{3} / \mathrm{yr}$ の沿岸漂砂が流れていたことから, 図-2 の両端から同量の沿岸漂砂が流入・流出していたため動 的平衡状態にあったと推定される.

この海岸において 1992 年までに 2 箇所にそれぞれ 2 基の離岸堤群からなるへッドランドが建設され，図-2 (b)のように離岸堤群 I， II の西側では直線的な汀線が 保持されたが，下手 (東) 側では汀線位置が大きく後退 するという海浜変形が生じた．例えば，写真-1 は 2005 年 10 月 14 日に離岸堤群 I を遠望したものである，手前 に設置された消波堤の端部から前方へと啋が堆積してバ 一ムが形成されている．汀線は全体に凹状であり，中央 部ではバームが護岸に非常に接近している。この付近で は護岸からの越波が激しく，かつ護岸表面が白いことか

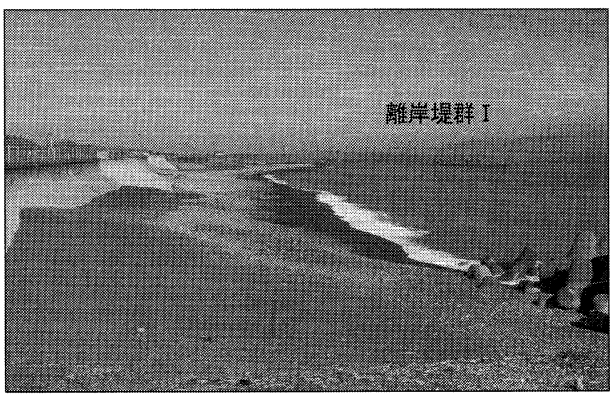

写真-1＼cjkstart離岸堤群 I（2005.10.14 撮影） 
ら，護岸前面の土砂が最近削り取られたことが明らかで ある。このような状況から護岸の被災を防止し，かつ越 波を低減させるために，毎年約 $3.5 \times 10^{4} \mathrm{~m}^{3}$ の養浜が行 われてきているが，投入後すぐに土砂が流出することか ら養浜の効果について疑問の声が出されている.

一方, 離岸堤群の設置により沿岸漂砂は自然状態で流 れていた $13 \times 10^{4} \mathrm{~m}^{3} / \mathrm{yr}$ と比較してかなり大きく減少し たはずである、離岸堤群沖の等深線の蛇行から離岸堤群 沖を沿岸漂砂の一部が通過していると推定されるが，実 際にいくらの沿岸漂砂低減効果があったかはこの図から は分からない。

\section{3. 動的平衡海浜の再現}

ここではまず自然状態にあった清水海岸の動的平衡状 態を再現し，その上で離岸堤群を設置して沿岸漂砂の制 御効果を調べた。図-1 には 2004 年 3 月の深浅図を示す が，この深浅図は図-2(b) と非常によく似ている。これ より離岸堤群の建設後この海岸がほぼ動的安定状態にあ ったことが分かる。このことから図-1に長方形で示す 沿岸方向に $1.4 \mathrm{~km}$, 岸沖方向に $500 \mathrm{~m}$ の区域を選定し, そこでの海浜変形を再現対象とした。この場合, 沿岸漂 砂は離岸堤群沖を一部が回り込みつつ下手へと流れてい ることから, 汀線変化モデルの適用は困難であり，3 次 元的な海浜変形を予測することが求められる.

このことから，海浜変形計算には芹沢ら（2002）の等 深線変化モデルを用いた。このモデルは平衡勾配とのバ ランスに依存した岸向き沖向きの漂砂と沿岸漂砂の作用 両者が取り込まれており，3 次元的な海浜変形予測が可 能である. 表-1にはこのモデルを用いた場合の計算条 件をまとめて示す。初期地形は 1989 年当時の自然地形 を宇多ら（1998）の展開座標の考え方にしたがい，緩や かに湾曲した汀線を直線に引き伸ばした座標を $\mathrm{x}$ 軸と し，これと直角沖向きにy 軸を定めた。初期海底勾配
は 1/10 とし，この座標系の中に離岸堤群などを配置し た. 現況再現計算は 1989 年から 2004 年まで 15 年間と し，そこで再現性を確認した上で 5 年後の海浜形状の予 測を行った。予測期間を 5 年としたのは現況で侵食が著 しく，早期の対応を求められているからである.

波浪条件については通常時の波浪ではなく，時化時の波 浪が海浜変形に大きな影響を及ぼすと考えて清水海岸での 波浪観測結果(静岡県，2004)上り5\%出現頻度の波浪(換 算沖波波高 $\mathrm{H}_{\mathrm{o}}{ }^{\prime}=3 \mathrm{~m}$ ，周期 $\mathrm{T}=9 \mathrm{~s}$ ) を選択した. 清水海岸 での波浪観測結果によると，卓越入射波向が $\mathrm{S}$ であるこ とから，沖合で $\mathrm{S}$ 方向の波浪を入射させた場合の屈折角 の変化を Snell の法則にしたがって算定し，研波点での入 射角を求めると $17^{\circ}$ となった，よってこの值をそのまま用 いた，その他重要な値として $h_{c}$ は $7 \mathrm{~m}, h_{R}$ は $3 \mathrm{~m}$ とし(宇 多，1997），平衡勾配は $1 / 10$ とした．鉛直方向の計算では $z=-7.5 \sim+3.5 \mathrm{~m}$ の範囲を $\Delta z=1 \mathrm{~m}$ のセルで分割した. この計算では，沖合の海底面は非常に緩いので沖合への土 砂の落ち込みはない. 境界条件として, 計算領域の右端か ら $Q_{\text {in }}=13 \times 10^{4} \mathrm{~m}^{3} / \mathrm{yr}$ の漂砂量を与え, 宇多・河野 (1996) の与えた 3 次式にしたがってその水深方向分布を与えた.
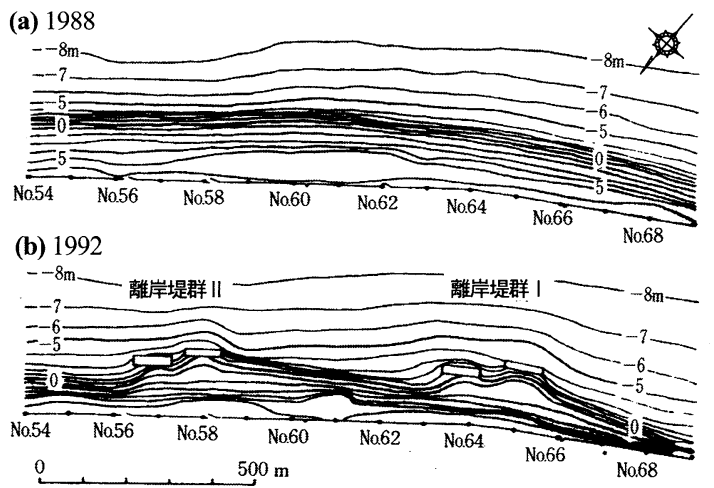

図-2 離岸堤群周辺の海浜変形

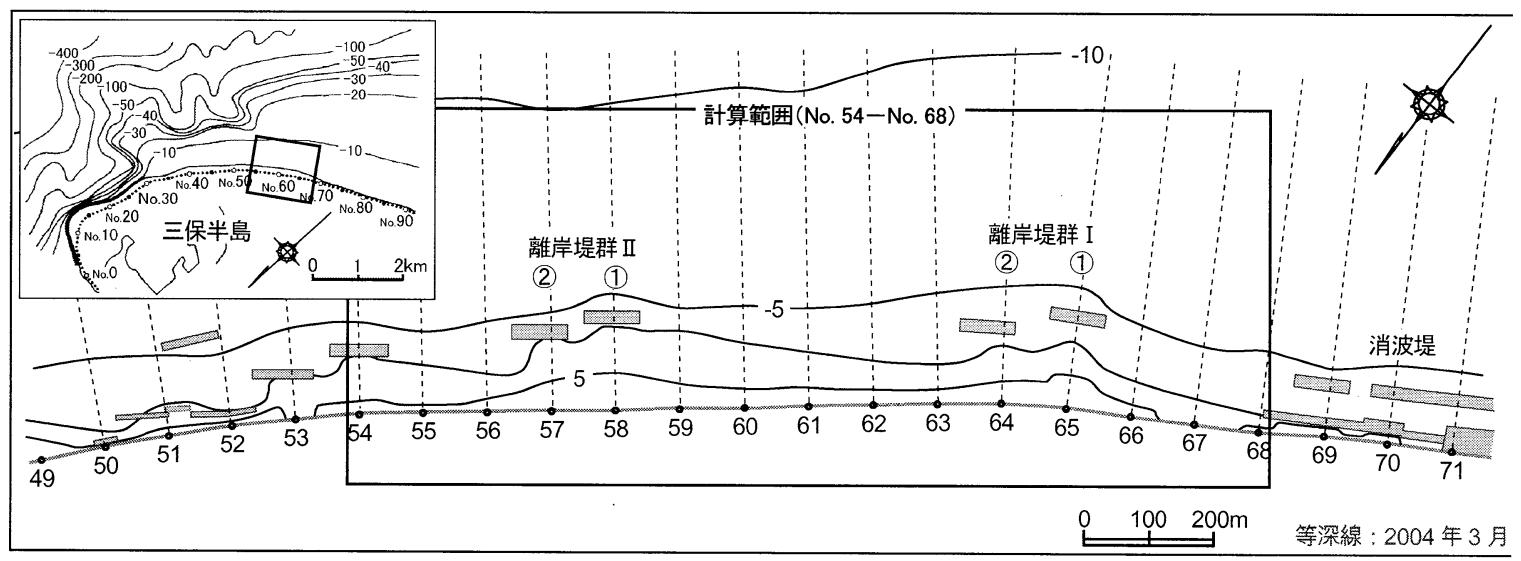

図-1 検討対象区域 
一方，左端の境界条件としては，各水深带に分布する 沿岸漂砂量が沿岸方向に不変という条件を与えた。沿岸 漂砂量係数を調整し, 自然海岸の場合の各点の $Q_{i}$ が $Q_{i n}$ に等しくなるようにすることで, 流入量と同量の沿 岸漂砂が左端から流出するようにした，その上で，計算 領域内の汀線が実測とほぼ一致し，かつ時間的に完全に 安定した動的安定海浜を再現した。この初期地形に離岸 堤群を設置し，表-1に示す高波浪を 15 年間作用させた。

図-3（a）は初期海浜と計算により求めた 10 年後の海 浜形状である，両者は完全に重なる，図-3(b)，(c) は 離岸堤群を配置した場合の海浜形状と, 実測汀線変化量 と計算汀線変化量 $\Delta Y$ の比較である. 計算では数年でこ の形状に近づき，ほぼ 10 年で 15 年後と同じ形状となっ て動的平衡状態に至る, 注目されるのは, 実際の養浜量 $3.5 \times 10^{4} \mathrm{~m}^{3}$ を手側から供給したのみでは上手端から 徐々に侵食が進み, 実際の汀線変化が再現されないこと である。このことから計算では上手側からの土砂供給量 を trial \& error で増加させ, 最終的に供給量が $7 \times 10^{4}$ $\mathrm{m}^{3} / \mathrm{yr}$ とすれば現況汀線でほほ動的平衡状態に達する ことが明らかになった。

図-3(b) は図-2 に示した実測深浅図と非常に良い対応 を示し, 離岸堤群の上手下手側の等哚線変化をうまく再 現している。また離岸堤群沖での等深線の蛇行について

表-1 計算条件

\begin{tabular}{|c|c|}
\hline 初期地形・構造物 & $\begin{array}{l}\text { 初期地形： } 1989 \text { 年当時の自然地形を展開 } \\
\text { 座標にモデル化した直線平行等深線地形 } \\
(\text { tan } \beta=1 / 10) \\
\text { 構造物：離岸堤群と将来対策施設 } \\
\end{array}$ \\
\hline 予測期間 & 5 年 \\
\hline 入射波条件 & $\begin{array}{l}5 \% \text { 程度出現頻度波: } \mathrm{Ho}^{\prime}=3 \mathrm{~m}, \mathrm{~T}=9 \mathrm{sec}, \\
\text { 波向 S(初期汀線への波の入射角 } \theta_{w}=17^{\circ} \text {, } \\
\text { 屈折考慮) }\end{array}$ \\
\hline 潮位条件 & M.S.L. $\fallingdotseq T . P .+0.0 \mathrm{~m}$ \\
\hline$h_{C}$ と $h_{R}$ & $h_{C}=7 \mathrm{~m} h_{R}=3 \mathrm{~m}$ \\
\hline 漂砂量係数 & $\begin{array}{l}\text { 沿岸漂砂量係数 } K_{x}=0.0042 \text { (自然状態で } \\
Q=13 \times 10^{4} \mathrm{~m}^{3} / \mathrm{yr} \text { の動的安定) 岸沖漂 } \\
\text { 砂量係数 } K_{z}=0.2 K_{x} \\
\text { 小笹・ブランプトン項の係数 } \\
K_{2}=1.62 K_{x}\end{array}$ \\
\hline 沿岸・岸沖漂砂の水深分布 & 宇多 - 河野 (1996) の3 次式 \\
\hline 平衡勾配 & $\tan \beta c=1 / 10$ \\
\hline 土砂落ち込みの限界勾配 & 陸上: $1 / 2$, 水中 : $1 / 2$ \\
\hline 計算等深線範囲 & $z=3.5 \mathrm{~m} \sim-7.5 \mathrm{~m}$ \\
\hline 計算メッシュ & 沿岸方向 $10 \mathrm{~m}$, 鉛直方向 $1 \mathrm{~m}$ \\
\hline 計算時間間隔 $\Delta t$ & $\Delta t=2 \mathrm{hr}$ \\
\hline 境界条件 & $\begin{array}{l}\text { 左端: } Q_{\mathrm{m}}=7 \times 10^{4} \mathrm{~m}^{3} / \mathrm{yr} \text { の土砂流入 } \\
\text { (維持養浜 + 自然供給) } \\
\text { 右端: 漂砂通過境界(等深線固定) } \\
\text { 岸沖端 }: q_{z}=0 \text { (漂砂の流出入なし) }\end{array}$ \\
\hline 消波構造物の波高伝達率 & 離岸堤 : $K_{t}=0.6$ \\
\hline 数値計算法 & 陽解法による差分法 \\
\hline 波浪計算法 & $\begin{array}{l}\text { 方向分散法（酒井ら，2002） } \\
S_{\text {max }}=25\end{array}$ \\
\hline
\end{tabular}

もうまく計算できた。等深線の蛇行は離岸堤群の沖を沿 岸漂砂が一部通過した場合に現れるものである. 図-3 (c) は実測汀線変化と計算值との比較であるが, 多少の 誤差は別にして全体的にかなりよく汀線変化を再現して いる.

\section{4. 離岸堤形状の改良と養浜による侵食軽減化}

\section{（1）養浜量の増減が周辺海岸に及ぼす影響}

清水海岸は動的平衡状態にある海岸のため, 安易に構 造物を設置すれば侵食域が拡大する恐れがある。そこで まず養浜量の増減と，砂投入位置が周辺海岸に及ぼす影 響について検討した．まず上手側からの毎年の土砂投入 量を $1 \times 10^{4} \mathrm{~m}^{3} / \mathrm{yr}$ 減少させた場合の汀線変化を図-4(a) に示す。この場合離岸堤群 I の上手側の広い区域で汀線 が大きく後退し，境界上（写真-1に示した付近）での 最大汀線後退量は $20 \mathrm{~m}$ 程度にもなる．このことは経費 がかかるという理由のみで養浜量を減少させると, 著し い侵食が生じることを意味する。ここで養浜量の減少の 可能性検討という本来の趣旨からはずれるが, 離岸堤群 の上手側に土砂を投入するのではなく, 離岸堤群 I の直 下手の侵食筒所に $1 \times 10^{4} \mathrm{~m}^{3} / \mathrm{yr}$ の追加的土砂投入を行 った結果が図-4(b)である。この方法は離岸堤群直下手 の汀線後退量の軽減にはそれなりの効果がある。しかし 毎年砂を入れ続けることにかなりの困難を伴う.

（2）離岸堤群を T 字突堤群に改良した場合の海浜変形 離岸堤群式ヘッドランドではとくに高波浪時など, 離

(a) 再現計算 : 自然状態 $\left(\theta_{i j}=13 \times 10^{4} \mathrm{~m}^{3} / \mathrm{yr}\right)$

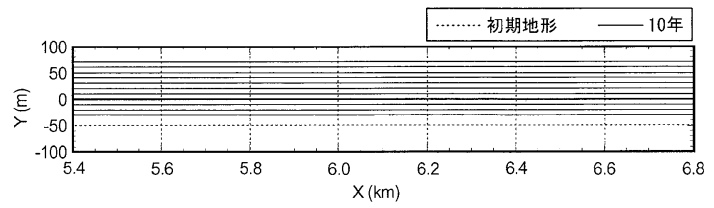

(b) 再現計算 : 動的安定 $\left(Q_{m}=7 \times 10^{4} \mathrm{~m}^{3} / \mathrm{yr}\right)$

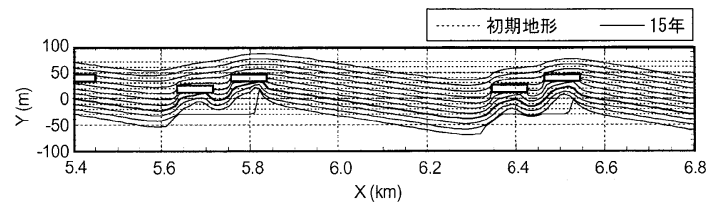

(c) 再現計算 : 実測汀線变化量と計算汀線の比較

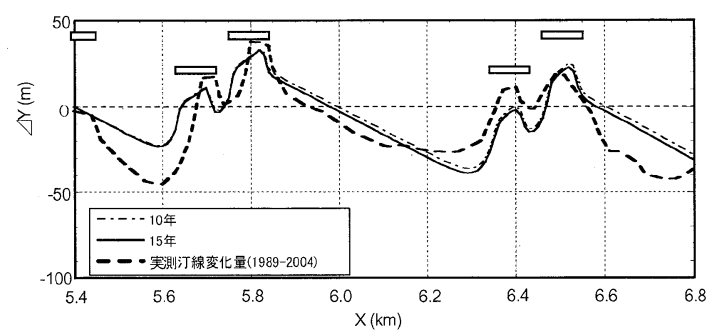

図-3 再現計算結果 
岸堤の背後を沿岸漂砂が通過し, 養浜砂が投入点付近に とどまらず下手方向へと急速に運ばれてしまうことから， 養浜の効果発現度が低いとの指摘がある．この点を調心゙ るために現状の維持養浜量を変えずに離岸堤を T 字突堤 として離岸堤背後における沿岸漂砂の通過を阻止した場 合の海浜変形予測を行った。離岸堤群 I の上手側離岸堤 のみを突堤化した場合の動的平衡状態にある等深線形状 を図-5 (a)に，汀線変化を図-5 (b)に示す，上手側一基の 離岸堤を T 字突堤化した場合, 突堤下手側で沿岸漂砂が 阻止されるため, 離岸堤群の背後に安定的に存在した舌 状砂州の消失を招く.このことから, 動的に平衡状態を 保ちつつ海岸を保全し, かつ現況海浜を劇的に変化させ

(a) 現状維持養浜量 $-1 \times 10^{4} \mathrm{~m}^{3} / \mathrm{yr} \quad\left(Q_{\text {in }}=6 \times 10^{4} \mathrm{~m}^{3} / \mathrm{yr}\right)$

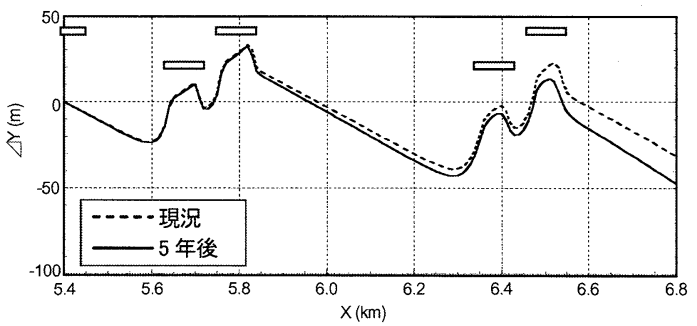

(b) 現状維持養浜量 $+1 \times 10^{4} \mathrm{~m}^{3} / \mathrm{yr} \quad\left(Q_{i n}=7 \times 10^{4} \mathrm{~m}^{3} / \mathrm{yr}\right)$

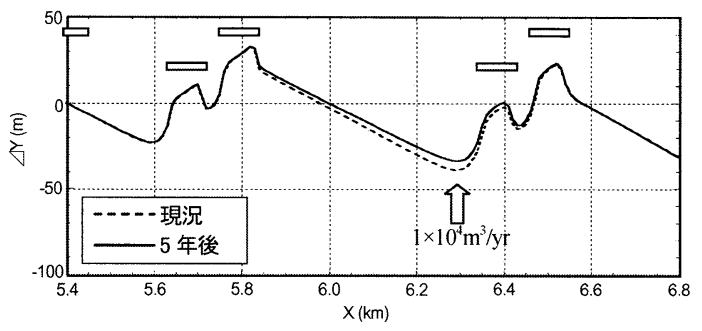

図-4 養浜量の増減が周辺海岸に及ぼす影響

(a) $\mathrm{T}$ 字突堤化 : 等深線形状 $\left(Q_{i n}=7 \times 10^{4} \mathrm{~m}^{3} / \mathrm{yr}\right)$

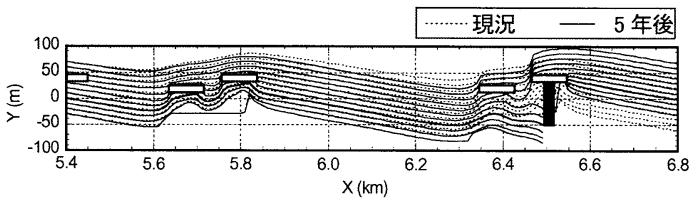

(b) $\mathrm{T}$ 字突堤化 : 離岸堤群 I -(1) $\left(Q_{i n}=7 \times 10^{4} \mathrm{~m}^{3} / \mathrm{yr}\right)$

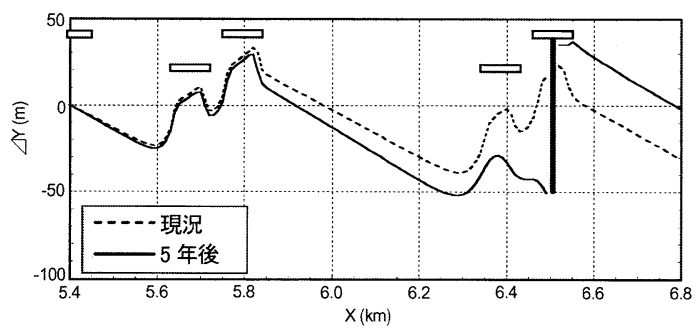

図-5離岸堤群をT字突堤群に改良した場合の汀線変化
ずに保全するには突堤は有効ではないことが分かった.

\section{（3）離岸堤を延伸した場合の海浜変形}

現在の維持養浜量を変えずに個々の離岸堤の堤長を $50 \mathrm{~m}$ 延長した場合について動的平衡海浜を求め, それ より汀線変化を抽出したのが図-6である。離岸堤 I (1)を上手側に延長した場合, 図-6(a)のように離岸堤群 I の上手側の汀線は前進するものの, 弱点である離岸堤 群 I の直下手では汀線後退量が $5 \mathrm{~m}$ 程度増大し逆効果 となる。離岸堤 I - (2)を下手側に延長した場合には, 図-6(b)のように離岸堤群 I の直下手の最大汀線後退箇 所が下手方向へ $50 \mathrm{~m}$ ずれる. しかし汀線後退量は初期 汀線と比較してあまり変わらない. 離岸堤 II - (1)を上手

(a) 離岸堤群 I - (1)延伸 $\left(Q_{i n}=7 \times 10^{4} \mathrm{~m}^{3} / \mathrm{yr}\right)$

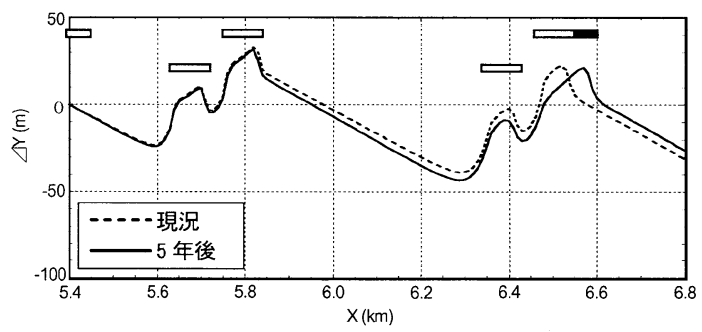

(b) 離岸堤群 I -(2)延伸 $\left(Q_{\text {in }}=7 \times 10^{4} \mathrm{~m}^{3} / \mathrm{yr}\right)$

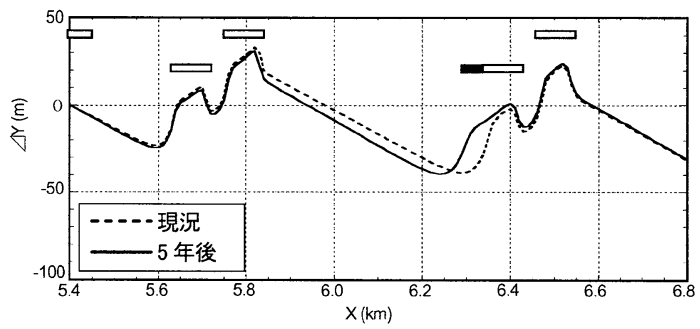

(c) 離岸堤群 II-(1) 延伸（ $\left.Q_{\text {in }}=7 \times 10^{4} \mathrm{~m}^{3} / \mathrm{yr}\right)$

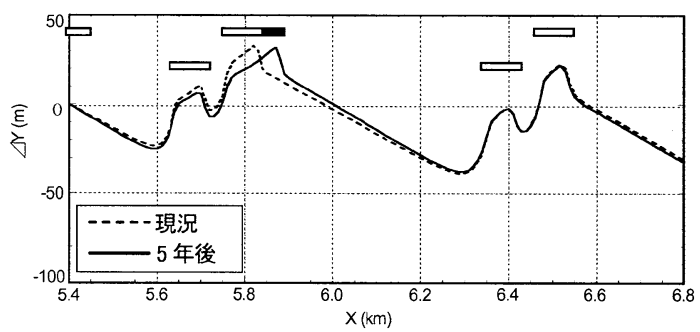

(d) 離岸堤群 I -(2), II-(1) 延伸 $\left(Q_{\text {in }}=7 \times 10^{4} \mathrm{~m}^{3} / \mathrm{yr}\right)$

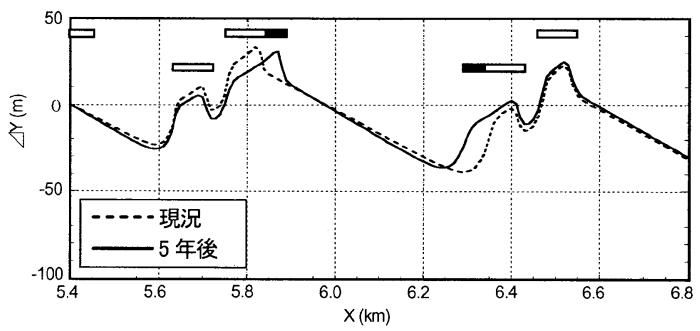

図-6 既設離岸堤を延伸した場合の汀線変化 
側に延長した場合，図-6(c)のように上手側の広い区域 で汀線が前進するが，離岸堤群間の距離が長いために離 岸堤群 I の直下手での汀線後退量の軽減には役立たない.

離岸堤 I - (2) と離岸堤 II - (1)を同時に延長した場合, 図-6(d)のように, 離岸堤群 I の直下手での最大侵食箇 所を下手側に $50 \mathrm{~m}$ ずらすと同時に, 汀線後退を軽減す ることができる．このことから離岸堤群間の距離を狭め ることは侵食防止上かなり効果が出ることがわかる。一 方，離岸堤群 Iの 2 基の離岸堤を同時に延長した場合は, 離岸堤群 Iの沿岸漂砂阻止効果が増加するため, 上手側 の汀線は大きく前進させることができるが, 直下手の汀 線の後退量が $5 \mathrm{~m}$ 程度増加する計算結果となった。

\section{（4）離岸堤群の延伸による養浜量低減の可能性検討}

前節までに，維持養浜量低減の上から見た検討として， 養浜量を単純に減少させる案や T 型突堤化案などを検 討したが十分な結果は得られなかった。一方，既設離岸 堤を延伸することで汀線後退をほどよく軽減できること がわかった．そこで各離岸堤の堤長を $80 \mathrm{~m}$ から $50 \mathrm{~m}$ 延長して離岸堤群間の距離を狭めた上で養浜量低減の可 能性について検討した．まず，現在の維持養浜と同量の 土砂投入を行った場合の汀線前進効果を調べた。等深線 形状を図-7 (a) に，汀線変化を図-7 (b) に示す。この場

(a) 離岸堤延伸 : 等深線形状 $\left(Q_{i n}=7 \times 10^{4} \mathrm{~m}^{3} / \mathrm{yr}\right)$

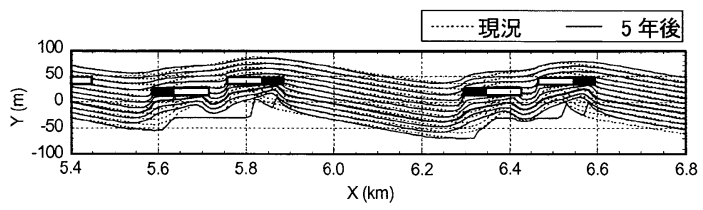

(b) 離岸堤延伸 $\left(Q_{\text {in }}=7 \times 10^{4} \mathrm{~m}^{3} / \mathrm{yr}\right)$

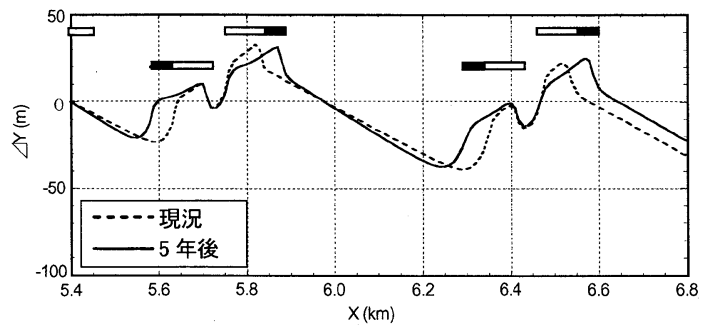

(c) 離岸堤延伸, 維持養浜- $1.0 \times 10^{4} \mathrm{~m}^{3} / \mathrm{yr} \quad\left(Q_{i n}=6.0 \times 10^{4} \mathrm{~m}^{3} / \mathrm{yr}\right)$

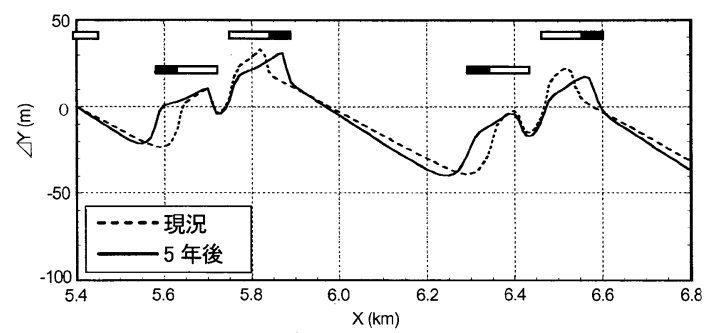

図-7 離岸堤延伸による養浜量低隇の検討
合，離岸题群 I の上手側の汀線は大きく前進するととも に, 離岸堤群 I の直下手の汀線後退が著しい点が下手側 に $50 \mathrm{~m}$ ずれると同時に, 最大汀線後退量が軽減した. このことからこの案はかなり有効である.

さらにこの形式による養浜量の低減の可能性について 上手側からの流入量を $6.5,6 \times 10^{4} \mathrm{~m}^{3} / \mathrm{yr}$ (投入土砂 量：現在の維持養浜量から $0.5,1.0 \times 10^{4} \mathrm{~m}^{3} / \mathrm{yr}$ 低減） とした場合の計算を行った。図-7 (c) は投入量を $1.0 \times 10^{4} \mathrm{~m}^{3} / \mathrm{yr}$ 低減させた場合の結果であるが，投入 土砂量の減少により上手側下手側の汀線は後退したもの の, 離岸堤群下手側での汀線後退量は図-7 (a)の場合と 大きな差異はない．このことから，すべての離岸堤を延 長することにより投入土砂量を減少させる上でかなり効 果的なことが分かる.

\section{5. 結 論}

(1)清水海岸の離岸堤群は，それらの設置以前の $13 \times 10^{4}$ $\mathrm{m}^{3} / \mathrm{yr}$ の沿岸漂砂が流れることによって動的平衡状 態にあった海岸において, 沿岸漂砂量を $7 \times 10^{4} \mathrm{~m}^{3}$ $/ \mathrm{yr}$ に低減させつつ動的平衡状態を作り出している.

(2)新たな動的平衡状態の沿岸漂砂量 $7 \times 10^{4} \mathrm{~m}^{3} / \mathrm{yr}$ はこ の海岸で行われてきている平均約 $3.5 \times 10^{4} \mathrm{~m}^{3} / \mathrm{yr}$ の 養浜量と比較して大きい. 上手側からわずかに漂砂供 給があるとは考えられるが，通過漂砂量より投入量が 小さいことは構造的な侵食傾向を招く.

(3このため離岸堤群の直下手では侵食が進み護岸の被災 が危惧される状態にあり，対策が必要とされている.

(4)離岸堤の突堤化はそのすぐ下手で激しい侵食を招くの で対策として有効ではない。

(5)既設離岸堤を下手・上手方向に $50 \mathrm{~m}$ 延長し, 間隔を 狭めると，現況の養浜量を $0.5 \sim 1.0 \times 10^{4} \mathrm{~m}^{3}$ 程度低 減させることができる.

\section{参 考 文 献}

宇多高明・河野茂樹 (1996)：海浜変形予測のための等深線変化モ デルの開発, 土木学会論文集, No.539/ II -35, pp. 121-139. 宇多高明 (1997)：「日本の海岸侵食」, 山海堂, p. 442 .

宇多高明・住谷廸夫 ·矢澤 肇・大谷靖郎・厚坂祐次 (1998)：展 開座標を用いた汀線変化モデルによる親沢鼻砂嘴の地形変化 予測, 海岸工学論文集, 第 45 巻, pp. 541-545.

酒井和也・小林昭男 - 宇多高明 - 芹沢真澄・熊田貴之 (2003)：波 の遮蔽構造物を有する海岸における 3 次元静的安定海浜形状 の簡易予測モデル，海岸工学論文集，第 50 巻, pp. 496-500.

芹沢真澄・宇多高明・三波俊郎・古池 鋼・熊田貴之 (2002)：海 浜縦断形の安定化機構を組み込んだ等深線変化モデル，海岸 工学論文集, 第 49 巻, pp. 496-500.

静岡県静岡土木事務所 (2004): 平成 16 年度清水西海岸高潮対策工 事に伴う養浜モニタリング調査業務委託報告書, 平成 17 年 3 月, p. 19. 